\title{
Renal Papillary Necrosis as the First Presenting Clinical Feature in a Sickle Beta and Thalassemic Child
}

\section{Jagadish Kumar, Satyesh Chowdary, Manjunath VG, Sudha Kiran Das and Manovihari Vuyyuru}

Department of Paediatrics, Jagadguru Sri Shivarathreeshwara Medical College, Jagadguru Sri Shivarathreeshwara University, Mysore, India

Correspondence:

Jagadish kumar

Department of Paediatrics

Jagadguru Sri Shivarathreeshwara Medical College,

Jagadguru Sri Shivarathreeshwara University,

Mysore, India

E-mail: jagdishmandya@gmail.com

DOI: $10.3126 /$ jnps.v40i3.29617

Submitted on: 2020-06-06

Accepted on: 2020-07-26

Acknowledgements: None

Funding: Nil

Conflict of Interest: None declared

Permission from IRB: Yes

To cite this article: Kumar J, Chowdary S, Manjunath VG, Das SK, Vuyyuru M. Renal Papillary Necrosis as the First Presenting Clinical Feature in a Sickle Beta and Thalassemic Child. J Nepal Paediatr Soc. $2020 ; 40(2): 274-7$.

\section{ABSTRACT}

In sickle cell disease (SCD), the clinical manifestations are due to episodes of vascular occlusion and haemolysis. Most of the children experience vaso-occlusive pain episodes by the age of six years. Renal injury in sickle cell disease referred to as sickle cell nephropathy is a frequent yet under-recognised complication. Renal papillary necrosis (RPN) as the first presentation in SCD is rare. We are reporting a 12 year old child with no prior vaso-occlusive episodes, presenting with renal papillary necrosis due to Sickle Beta and Thalassemia.

Key Words: Renal Papillary Necrosis; Sickle Beta and Thalassemia; Sickle Cell Disease; Sickle Cell Nephropathy

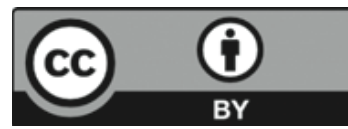

This work is licensed under creative common attribution 3.0 license 


\section{INTRODUCTION}

Sickle cell disease (SCD) is a group of haemoglobinopathies in which the sickle haemoglobin mutation is co-inherited with another beta globin mutation, for example HbSS, Sicklebeta thalassemia, HbSC disease. ${ }^{1,2}$ The clinical presentations of SCD are due to episodes of vascular occlusion and haemolysis which lead to organ dysfunction and pain. ${ }^{1}$ In SCD children, nearly two thirds experience vaso-occlusive pain episodes by the age of two years and 90 percent experience it by the age of six years. ${ }^{1,2}$ Renal injury in SCD, referred to as sickle cell nephropathy $(\mathrm{SCN})$, is a frequent yet under-recognised complication. ${ }^{2,3}$ Renal papillary necrosis (RPN) as the first presentation of SCD is rare. ${ }^{4,5} \mathrm{We}$ are reporting RPN as the first presenting clinical feature in a 12 year old Sickle Beta and Thalassemic child.

\section{CASE REPORT}

A 12 year old developmentally normal boy presented with acute onset abdominal pain for one day and back pain since morning. Pain was sharp in nature with no history of radiation and any significant aggravating or relieving factors. There was no history of fever, trauma, vomiting, loose stool and bladder disturbances. There was no past history of recurrent abdominal pain, chest pain, arthralgias or diabetes mellitus. At admission he was wincing with back pain and tossing over in bed. On examination, temperature was $100^{\circ} \mathrm{F}$, pulse rate was 102 / minute, respiratory rate 20 breaths / minute, BP 124/80 $\mathrm{mm}$ of $\mathrm{Hg}$, CFT $<3$ secs and $\mathrm{SP}_{2}-97 \%$ at room air. His weight was $22.3 \mathrm{~kg}(<$ 3 rd centile as per WHO centile chart) and height 130 centimeters (between $3^{\text {rd }}$ and $15^{\text {th }}$ centile). He was pale and there was no icterus. Abdomen was soft with severe bilateral renal angle tenderness. Firm, non-tender four centimetre spleen was also palpable. Other systemic examinations were unremarkable. In view of bilateral renal angle tenderness, diagnosis of acute pyelonephritis / trauma was considered. Abdominal sonography revealed bilateral hypoechoic cortical echotexture of kidneys with hyperechoic renal sinus echogenicity, suspicious of pyelonephritis. Investigations are depicted in the table 1 . Child was started on IV antibiotics (ceftriaxone and amikacin). The child gradually improved with medical management on subsequent days. On fifth day, a repeat abdominal sonography was done which showed similar findings to that which was present at the time of admission. On eighth day he was clinically stable. In view of pallor with persistent splenomegaly, we reviewed our diagnosis, suspecting vaso-occlusive crisis of sickle cell disease. His sickling test was positive. Haemoglobin electrophoresis was sent. On tenth day, contrast CT abdomen revealed renal papillary necrosis. $\mathrm{Hb}$ electrophoresis revealed features suggestive of double heterozygous $\mathrm{HbS} /$ Beta thalassemia. He was discharged after 14 days of antibiotics and started on hydroxyurea for SCD.

\section{DISCUSSION}

In SCD, pain episodes usually occur by six years of age and common sites are chest, extremities, the back and abdomen. ${ }^{1}$ However, our patient had no history of any vaso-occlusive crisis since birth till the time of his presentation to us. The age of onset of $\mathrm{SCN}$ is variable in SCD. ${ }^{2} \mathrm{SCN}$ is less common in milder genotypes. ${ }^{1,2}$ The incidence of renal complications in SCD has been estimated to be $68 \%$, out of which 30 to $40 \%$ have RPN. ${ }^{2,3,6} \mathrm{~A}$ study from Nigeria assessed 220 adult sickle cell patients and found only $2.3 \%$ of subjects having RPN. ${ }^{3}$ A study in Saudi Arabia observed that 45\% of patients with SCD had urological complications with 4\% diagnosed with RPN. ${ }^{7}$ In a study at Mayo Clinic, 165 patients with RPN were evaluated and only $3 \%$ had SCD. ${ }^{8}$ The spectrum of clinical features of RPN range from asymptomatic microscopic haematuria to acute pain, fever and even obstructive acute renal failure. ${ }^{3,6}$ Hematuria occurs in $6 \%$ of children with SCD. ${ }^{1,6}$ Common causes of hematuria and flank pain in SCD include RPN and urinary tract infections. ${ }^{2}$ Incidence of urinary tract infections and pyelonephritis are more common in patients with SCD than the general population. $^{2}$ However in our child serial urine monitoring could not detect microscopic haematuria and urine culture was sterile.

As our patient presented with bilateral renal angle tenderness, differential diagnoses of acute pyelonephritis and trauma were considered. 
Table 1. Investigations

\begin{tabular}{|c|c|c|c|c|}
\hline Investigations & $\underset{\text { Admission }}{\text { Adm }}$ & 6th day & $\begin{array}{l}\text { 10th } \\
\text { Day }\end{array}$ & $\begin{array}{l}\text { 11th } \\
\text { Day }\end{array}$ \\
\hline $\begin{array}{l}\text { Hemoglobin } \\
{[\mathrm{g} / \mathrm{dl}]}\end{array}$ & 10 & 9.8 & & \\
\hline $\operatorname{PCV}(\%)$ & 29.4 & 28.7 & & \\
\hline TLC (cells $\left./ \mathrm{mm}^{3}\right)$ & 13300 & 11460 & & \\
\hline $\begin{array}{l}\text { Differential } \\
\text { count }\end{array}$ & $\begin{array}{r}86 \% \\
\text { Neutrophils } \\
10 \% \\
\text { Lymphocytes }\end{array}$ & $\begin{array}{l}61 \% \mathrm{~N} \\
28 \% \mathrm{~L}\end{array}$ & & \\
\hline ESR & $\begin{array}{r}20 \mathrm{~mm} 1 \mathrm{st} \\
\text { hour }\end{array}$ & & & \\
\hline $\begin{array}{l}\text { Platelet count } \\
\left(\text { cells } / \mathrm{mm}^{3}\right)\end{array}$ & 2.12 lakh & $\begin{array}{l}2.32 \\
\text { lakh }\end{array}$ & & \\
\hline $\begin{array}{l}\text { Serum bilirubin } \\
(\mathrm{mg} / \mathrm{dl})\end{array}$ & 1.17 & & & \\
\hline SGOT (U/L) & 47 & & & \\
\hline SGPT (U/L) & 14 & & & \\
\hline $\begin{array}{l}\text { Serum Total } \\
\text { Protein (gm/dl) }\end{array}$ & 7.4 & & & \\
\hline $\begin{array}{l}\text { Serum Albumin } \\
(\mathrm{gm} / \mathrm{dl})\end{array}$ & 4.7 & & & \\
\hline $\begin{array}{l}\text { Blood Urea } \\
(\mathrm{mg} / \mathrm{dl})\end{array}$ & 17 & & & 23 \\
\hline $\begin{array}{l}\text { Serum } \\
\text { Creatinine } \\
(\mathrm{mg} / \mathrm{dl})\end{array}$ & 0.39 & 0.42 & & 0.46 \\
\hline $\begin{array}{l}\text { Uric acid } \\
(\mathrm{mg} / \mathrm{dl})\end{array}$ & 4.2 & & & \\
\hline $\begin{array}{l}\text { Serum Sodium } \\
(\mathrm{mEq} / \mathrm{L})\end{array}$ & 133 & & & 136 \\
\hline $\begin{array}{l}\text { Serum Potassium } \\
(\mathrm{mEq} / \mathrm{L})\end{array}$ & 4 & & & 4.7 \\
\hline $\begin{array}{l}\text { Serum Chloride } \\
(\mathrm{mEq} / \mathrm{L})\end{array}$ & 97 & & & 96 \\
\hline $\begin{array}{l}\text { Serum Amylase } \\
(\mathrm{N}=13-53 \mathrm{U} / \mathrm{L})\end{array}$ & 52 & & & \\
\hline $\begin{array}{l}\text { Serum Lipase }(\mathrm{N} \\
=13-60 \mathrm{U} / \mathrm{L})\end{array}$ & 34 & & & \\
\hline $\begin{array}{l}\text { Urine Albumin } \\
\text { Sugar } \\
\text { RBCs } \\
\text { Pus cells } \\
\text { (cells/HPF) }\end{array}$ & $\begin{array}{l}\text { Nil } \\
\text { Nil } \\
\text { Nil } \\
1-2\end{array}$ & $\begin{array}{l}\text { Nil } \\
\text { Nil } \\
\text { Nil } \\
\text { Nil }\end{array}$ & $\begin{array}{l}\text { Nil } \\
\text { Nil } \\
\text { Nil } \\
1-2\end{array}$ & \\
\hline
\end{tabular}

Ultrasonography at admission was also suggestive of pyelonephritis. His urine microscopy was normal and culture was sterile. Even though fever lasted only for three days, in view of pallor with persistent splenomegaly we reviewed our diagnosis, suspecting vaso-occlusive crisis of sickle cell disease. His electrophoresis confirmed $\mathrm{HbS} /$ Beta thalassemia. Contrast CT abdomen revealed RPN.

Sensitivity of sonography for the detection of acute pyelonephritis ranges from $25 \%$ to $50 \% .{ }^{9}$ Findings include nephromegaly, abnormal parenchymal echogenicity, deficient corticomedullary differentiation, renal sinus hyper echogenicity and urothelial thickening. Sonography in SCD shows mild diffuse enlargement, hyper echogenicity and loss of cortico medullary differentiation. ${ }^{9}$

Other than SCD, pyelonephritis, analgesic abuse, urinary tract obstruction, interstitial nephritis, tuberculosis, diabetes mellitus, renal vein thrombosis, and liver cirrhosis also can lead to RPN. These causes are usually not encountered in children. ${ }^{3,10}$ We ruled out all these causes by history, examination and appropriate investigations.

He never had episodic pains till 12 years of age and suddenly presented with severe abdominal pain and finally diagnosed as RPN due to SCD. RPN as the first presenting feature of SCD is uncommon. Similar to our case, Alebiosu reported RPN as the first presentation in a 25 years old Nigerian SCD patient. ${ }^{4}$ Voulgarelis and Ziakas also reported RPN unmasking sickle cell-beta thalassemia in a 26 years old female. ${ }^{5}$ Our patient was distinctive as RPN prompted the diagnosis of sickle cell disease. Our patient was unique as he presented with RPN as the presenting clinical feature of underlying SCD.

\section{CONCLUSIONS}

RPN can be the presenting feature of underlying SCD in young children. A child with acute bilateral loin pain may not always be due to acute pyelonephritis, other causes like RPN should also be kept in mind. Keeping the possibility of venoocclusive crisis in mind, SCD should also be considered in the differential diagnosis of young children presenting with bilateral loin pain and RPN. 


\section{REFERENCES}

1. Vichinsky E P. Overview of the clinical manifestations of sickle cell disease.Ed. DeBaun M R.www.uptodate.com (C2020 UpToDate. Wolters Kluwer. Topic last updated: Dec 03, 2019.Accesed on 1/6/20.

2. Lerma E V, Vichinsky EP. Renal manifestations of sickle cell disease.Ed. Curhan G C,DeBaun M R.www.uptodate.com (C2020 UpToDate. Wolters Kluwer.Topic last updated: Nov 19, 2019.Accesed on 1/6/20.

3. Madu A J, Okoye A E, Ajuba I C, Madu K A, Anigbo C, Agu K. Prevalence and associations of symptomatic renal papillary necrosis in sickle cell anemia patients in South-Eastern Nigeria. Niger J Clin Pract. 2016;19:471-4. DOI: $10.4103 / 1119-3077.183299$

4. Alebiosu C O. Renal Papillary Necrosis as First Presentation of a Nigerian Sickle Cell Patient. West Afr J Med. 2002; 21:168-9. PMID: 12403047

5. Voulgarelis M, Ziakas P D. Renal Papillary Necrosis Unmasking Sickle Cell Disease. N Engl J Med. 2005;352: 1237-9. DOI: 10.1056/NEJMicm030682.

6. Alhwiesh A. An update on sickle cell nephropathy. Saudi J Kidney Dis Transpl. 2014;25:249-658. DOI: 10.4103/1319-2442.128495.PMID: 24625990

7. Alamri AA. Prevalence of Urological Complications Associated with Sickle Cell Disease. Bahrain Med Bull. 2019; 41:90-927.

8. Griffin MD, Bergstralhn EJ, Larson TS. Renal papillary necrosis-a sixteen-year clinical experience. J Am Soc Nephrol. 1995;6:248-56. PMID: 7579092

9. Brian d. Coley. Caffey's Pediatric Diagnostic Imaging. Thirteenth Edition. Elsevier, Inc. 2019. 1111p, 1131p.

10. Henderickx MMEL, Brits T, De Baets K, Seghers M, Maes P, Trouet D, et al. Renal Papillary Necrosis in Patients with Sickle Cell Disease: How to Recognise This "Forgotten" Diagnosis. J Pediatr Urol. 2017;13:250-6. DOI: 10.1016/j.jpurol.2017.01.020 